\title{
ANALISIS PENGELOLAAN LIMBAH MEDIS PUSKESMAS DI KECAMATAN BABULU KABUPATEN PENAJAM PASER UTARA BERDASARKAN PERMENKES NOMOR 27 TAHUN 2017
}

\author{
Amrullah \\ Fakultas Kesehatan Masyarakat \\ Universitas Mulawarman
}

\begin{abstract}
The amount of medical waste originating from health facilities are expected progressively increasing. Waste generated from medical efforts such as health centers, polyclinics and hospitals are the type of waste which are included in the category of biohazard waste is very dangerous type of environment, where many exiles viruses, bacteria and other harmful substances. This study was conducted to analyze the management of solid medical waste in the public health centers in Kecamatan Penajam Kabupaten Penajam Paser Utara Provinsi Kalimantan Timur.

This research is a qualitative descriptive. The object of research is the implementation of medical waste management in health centers and community health centers target sanitarians and janitor. The research variables include the characteristics of medical waste, stage management, medical waste management officers, facilities, SOP and the perceived health impact of medical waste management officers.

The results showed solid medical waste management of health centers is not in accordance with the applicable provisions of the color of plastic bags are used not appropriate, storage locations are not eligible, and there are medical waste that is not destroyed by incineration. Medical waste management facilities not adequate ie no conveyance and no incinerators. Medical waste management is done not in accordance with the SOP and SOP is not in accordance with regulations. Medical waste management officers not using PPE.

It is advisable to do a lug medical waste with a plastic bag, label and symbol in accordance with existing regulations. Medical waste storage location is advisable to be in a secure area and symbols and labels. Waste disposal is done in the health center in order to keep attention to the existing guidelines to minimize the risk. The need for training on medical waste management and use of PPE.
\end{abstract}

Keywords : management, medical waste, health centers

\section{ABSTRAK}

Jumlah limbah medis yang bersumber dari fasilitas kesehatan diperkirakan semakin lama semakin meningkat. Limbah yang dihasilkan dari upaya medis seperti puskesmas, poliklinik dan rumah sakit yaitu jenis limbah yang termasuk dalam kategori biohazard yaitu jenis limbah yang sangat membahayakan lingkungan, dimana banyak terdapat buangan virus, bakteri maupun zat yang membahayakan lainnya. Penelitian ini dilakukan untuk menganalisis pengelolaan limbah medis puskesmas di Kecamatan Babulu Kabupaten Penajam Paser Utara.

Penelitian ini merupakan penelitian deskriptif kualitatif. Objek penelitian yaitu pelaksanaan pengelolaan limbah medis padat pada puskesmas dan sasarannya sanitarian puskesmas dan petugas kebersihan. Variabel penelitian ini meliputi 
karakteristik limbah medis, tahapan pengelolaan, petugas pengelola limbah medis, sarana, SOP dan dampak kesehatan yang dirasakan petugas pengelola limbah medis.

Hasil penelitian menunjukkan pengelolaan limbah medis puskesmas belum sesuai dengan ketentuan yang berlaku yaitu warna kantong plastik yang digunakan belum sesuai, lokasi penyimpanan tidak memenuhi syarat, dan masih terdapat limbah medis yang tidak dimusnahkan dengan insinerator. Sarana pengelolaan limbah medis padat belum memadai yaitu tidak ada alat pengangkut dan tidak ada insinerator. Pengelolaan limbah medis padat yang dilakukan tidak sesuai dengan SOP, dan SOP belum sesuai dengan peraturan. Petugas pengelola limbah medis belum menggunakan APD.

Disarankan untuk melakukan pewadahan limbah medis dengan kantong plastik, label dan simbol sesuai dengan peraturan yang ada. Lokasi penyimpanan limbah medis disarankan untuk berada di area yang aman dan diberi simbol dan label. Pemusnahan limbah yang dilakukan di lingkungan puskesmas agar tetap memperhatikan pedoman yang ada untuk meminimalkan resiko. Perlu adanya pelatihan mengenai pengelolaan limbah medis dan penggunaan APD.

Kata kunci : pengelolaan, limbah medis padat, puskesmas

\section{PENDAHULUAN}

Berdasarkan Peraturan

Menteri Kesehatan Republik Indonesia Nomor 75 tahun 2014 Pusat Kesehatan Masyarakat yang selanjutnya disebut dengan Puskesmas adalah fasilitas pelayanan kesehatan yang menyelenggarakan upaya kesehatan masyarakat dan upaya kesehatan perseorangan tingkat pertama, dengan lebih mengutamakan upaya promotif dan preventif, untuk mencapai derajat kesehatan masyarakat yang setinggi-tingginya di wilayah kerjanya.

Salah satu dampak dari kegiatan pelayanan kesehatan di puskesmas yaitu timbulnya limbah. Menurut Undang-undang No. 32 Tahun 2009 tentang Perlindungan dan Pengelolaan Lingkungan Hidup, limbah merupakan sisa suatu usaha dan/ atau kegiatan, sedangkan pencemaran lingkungan adalah masuk atau dimasukkannya makhluk hidup, zat, energi, dan/atau komponen lain ke dalam lingkungan hidup oleh kegiatan manusia sehingga melampaui baku mutu lingkungan hidup yang telah ditetapkan.

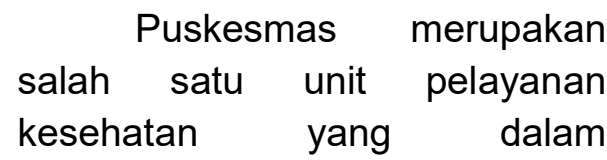
kegiatannya menghasilkan limbah medis maupun limbah non medis baik dalam bentuk padat maupun cair. Limbah medis adalah semua bahan limbah yang dihasilkan di fasilitas pelayanan kesehatan, seperti rumah sakit, klinik, kantor dokter, praktek gigi, bank darah, dan rumah sakit hewan/ klinik, serta fasilitas penelitian medis dan laboratorium (WHO, 2014).

Limbah medis yang dihasilkan oleh rumah sakit/ puskesmas diantaranya limbah radioaktif, limbah infeksius, patologi dan anatomi, limbah 
sitotoksis, limbah kimia dan farmasi (Kemenkes RI, 2004). Pengelolaan limbah B3 adalah salah satu masalah paling serius di fasilitas kesehatan dikarenakan limbah medis terutama limbah infeksius sangat potensial dalam transmisi penyakit menular baik melalui kontak langsung atau tidak langsung melalui media lingkungan. Oleh karena itu, limbah medis tidak boleh dibuang langsung ke dalam media lingkungan hidup tanpa diolah terlebih dahulu. Untuk menghindari risiko dan gangguan kesehatan maka pemerintah menetapkan Keputusan Menteri Kesehatan RI No. 1204/Menkes/SK/X/2004

mengenai Persyaratan Kesehatan Lingkungan Rumah Sakit, Peraturan Pemerintah No. 101 tahun 2014 tentang Pengelolaan Limbah B3. Secara lebih rinci, pengelolaan limbah B3 termasuk limbah medis diatur didalam Peraturan Menteri Lingkungan Hidup No.14 tahun 2013 tentang Simbol dan Label Limbah Bahan Berbahaya dan Beracun, dan Keputusan Kepala Bapedal No. 1 Tahun 1995 tentang: Tata Cara dan Persyaratan Teknis Penyimpanan Dan Pengumpulan Limbah Bahan Berbahaya dan Beracun.

Adanya pengelolaan limbah medis yang tepat dan benar sesuai dengan peraturan yang telah ditetapkan dan juga pengawasan yang tegas terhadap pengolahan limbah medis yang dihasilkan dari fasilitas pelayanan kesehatan, dapat mencegah terjadinya penularan penyakit ataupun pencemaran lingkungan sehingga kesehatan masyarakat dan lingkungan dapat terjamin.

Berdasarkan data

persentase provinsi yang melakukan pembinaan pengelolaan limbah medis fasilitas pelayanan kesehatan (fasyankes) tahun 2013, Provinsi Kalimantan Timur baru mencapai $21 \%$ dari total fasyankes yang ada (Dirjen PP \& PL, 2014).

Kabupaten Penajam Paser Utara merupakan salah satu wilayah di Provinsi Kalimantan Timur yang dihuni 187.690 penduduk yang tersebar di empat kecamatan. Kecamatan Babulu diketahui merupakan wilayah yang cukup banyak penduduknya, yaitu sekitar 34.961 penduduk $(47,44 \%$ dari total penduduk di Kabupaten Penajam Paser Utara).

Data dari Kementerian Kesehatan RI tahun 2013, puskesmas di Kabupaten Penajam Paser Utara berjumlah 11 unit, 9 diantaranya adalah jenis puskesmas rawat inap. Wilayah Kecamatan Babulu sendiri memiliki 3 puskesmas yang terdapat di Kelurahan 
Babulu, Desa Gunung Intan, dan Desa Sebakung Jaya.

Terkait dengan pengelolaan limbah medis Puskesmas di Kecamatan Babulu terdapat kendala berdasarkan hasil studi pendahuluan di salah satu Puskesmas, yaitu masih terdapat puskesmas yang belum memiliki incinerator namun memiliki MOU dengan RS yang berada di Kabupaten Penajam Paser Utara, terkadang terjadi penumpukan limbah karena minimnya anggaran operasional pengelolaan limbah tersebut, peran petugas belum dilaksanakan sesuai dengan tugas dan fungsinya karena minimnya SDM sanitarian yang berada disetiap Puskesmas sehingga masih terdapat adanya limbah yang belum tertangani secara serius dan pengelolaan limbah medis padat di puskesmas masih belum bisa disebut sempurna dikarenakan belum lengkapnya sarana dan prasarana yang ada. Hal tersebut menunjukkan belum adanya perhatian khusus terhadap pengelolaan limbah medis yang dihasilkan dari kegiatan puskesmas.

\section{METODE PENELITIAN}

Jenis penelitian yang digunakan adalah penelitian observasional yang bersifat deskriptif karena menggambar- kan sistem pengelolaan limbah medis puskesmas secara obyektif tanpa memberikan perlakuan terhadap obyek. Penelitian ini termasuk dalam penelitian deskriptif kualitatif.

Penelitian ini dilakukan di seluruh Puskesmas di Kecamatan Babulu, yaitu Puskesmas Babulu, Puskesmas Gunung Intan dan Puskesmas Sebakung Jaya. Penelitian ini dilakukan mulai bulan Februari sampai dengan Maret 2018.

Pada penelitian ini menggunakan triangulasi sumber dengan melibatkan informan utama, informan pendukung, dan informan kunci. Triangulasi diartikan sebagai teknik pengumpulan data yang bersifat menggabungkan dari beberapa tekhnik data dan sumber data yang telah ada. Triangulasi berarti peneliti menggunakan teknik pengumpulan data dari sumber yang sama. Peneliti menggunakan observasi partisipatif, wawancara mendalam, dan dokumentasi untuk sumber data yang sama secara serempak. Triangulasi berarti untuk mendapatkan data dari sumber yang berbeda-beda dengan teknik yang sama (Sugiyono, 2014).

Adapun cara pemilihan sumber dalam penelitian ini menggunakan teknik purposive sampling. Hal itu sesuai dengan 
(Moleong, 2007) yang
menyatakan bahwa pada
penelitian kualitatif tidak ada
sampel acak, tetapi sampel
bertujuan (purposive sample).
Purposive sampling adalah teknik
penentuan sample dengan
pertimbangan tertentu.

\section{Informan Utama} Informan utama yang dimaksud yaitu tenaga kesehatan lingkungan puskesmas. Dengan tekhnik purposive sampling, maka pemilihan informan utama dilakukan dengan cara mengambil subjek yang disesuaikan dengan kriteria permasalahan yang diteliti yaitu tenaga kesehatan lingkungan di puskesmas.

\section{Informan Pendukung} Informan pendukung yang dimaksud disini adalah pengelola gudang obat.

\section{Informan Kunci Informan kunci yang dimaksud disini adalah Pimpinan Puskesmas.}

\section{HASIL DAN PEMBAHASAN Hasil}

Dari hasil wawancara
antara informan utama dan
informan kunci didapati hasil
bahwa proses pengumpulan,
pemilahan, sampai dengan
penyimpanan limbah medisnya

masih banyak belum sesuai dalam pengelolaannya, sehingga peneliti mewawancarai petugas kebersihannya sebagai informan pendukung agar mendapatkan informasi yang lebih dalam dilapangan. Dari hasil wawancara oleh informan pendukung didapatkan hasil yang menguatkan informasi dari informan utama dan informan kunci, bahwa pengelolaan limbah medis di puskesmas Gunung Intan sangat sederhana dan dilakukan secara mandiri tidak menggunakan pihak ke dua dalam pemusnahan limbah medisnya.

Selama bekerja sebagai petugas pengelola limbah medis padat puskesmas, para petugas jarang memeriksakan kesehatannya baik pemeriksaan awal maupun pemeriksaan secara berkala. Sedangkan berdasarkan hasil wawancara, tidak mengalami keluhan kesehatan yaitu gangguan pada saluran pernafasan. Untuk kejadian tertusuk limbah medis benda tajam, petugas kebersihan mengakui belum pernah mengalaminya, karena selama ini limbah medis benda tajam dikumpulkan dalam safety box. 
Pembahasan

Karakteristik, pemilahan,
pewadahan dan pemanfaatan
kembali Limbah Medis di
Kecamatan Babulu

Limbah medis puskesmas yang ada di Kecamatan Babulu dihasilkan dari kegiatan pelayanan kesehatan yang ada di tiap ruangan seperti ruang tindakan, ruang gigi, KIA, laboratorium, apotek, rawat inap, UGD dan ruang imunisasi. Jenis limbah yang dihasilkan berupa handscoon, masker, jarum suntik, spet, botol infus, selang infus, kapas, perban bekas, botol obat, plester, sisa obat, dan lain-lain.

Pada tahap pengumpulan dan pemilahan, puskesmas di Kecamatan Babulu melakukan pemilahan dengan menyiapkan dua bak sampah di setiap ruang pelayanan, yaitu bak sampah medis dan bak sampah non medis. Bak sampah terbuat dari bahan plastik, ringan, kedap air, mudah dibersihkan dan memiliki penutup. Bak sampah dilapisi dengan kantong plastik berwarna merah. Tidak ada perbedaan warna kantong plastik yang digunakan, kedua bak sampah menggunakan kantong plastik berwarna merah. Terdapat label pada bak sampah yang bertuliskan "sampah medis" dan "sampah non medis", namun tidak terdapat simbol atau lambang limbah pada bak sampah tersebut. Limbah medis padat tersebut tidak ada yang dimanfaatkan kembali ataupun didaur ulang.

Tahap pengumpulan, pengangkutan dan penyimpanan limbah medis di lingkungan puskesmas Kecamatan Babulu

Tahap pengumpulan limbah medis padat dari setiap ruangan yang ada di puskesmas dilakukan oleh petugas kebersihan setiap hari. Kegiatan pengumpulan ini dilakukan setelah jam pelayanan selesai sekitar pukul 14.00 WITA. Petugas kebersihan akan berkeliling dan mengumpulkan limbah medis dari setiap ruangan, pengangkutan dilakukan pada jam tersebut dikarenakan aktifitas Puskesmas telah berhenti sehingga tidak menggangu pengunjung dan pegawai puskesmas dalam proses pengangkutan limbah.

Pengangkutan limbah medis padat yang dilakukan di Puskesmas Babulu langsung dengan kantong plastiknya. Tidak ada alat angkut khusus yang digunakan petugas kebersihan untuk mengangkut limbah medis dari tiap ruangan ke tempat pengumpulan limbah medis. Kantong plastik berisi limbah medis padat langsung dibawa ke tempat pengumpulan limbah 
medis yang berada di bagian samping bangunan rawat inap dan UGD. Kantong plastik berisi limbah medis padat tersebut diikat, kemudian dimasukkan ke dalam drum yang telah disiapkan untuk penyimpanan limbah medis.

\section{Pengumpulan, pengemasan} dan pengangkutan ke luar puskesmas Kecamatan Babulu

Dari tiga puskesmas yang ada di Kecamatan Babulu, hanya Puskesmas Babulu yang melakukan pengolahan limbah medis keluar puskesmas. Sedangkan Puskesmas Gunung Intan dan Puskesmas Sebakung Jaya melakukan pengolahan limbah medis padat di dalam lingkungan puskesmas.

Limbah medis yang telah dikumpulkan di Puskesmas Babulu dalam kurun waktu \pm 1 bulan diangkut ke RSUD Penajam Paser Utara untuk dilakukan pengolahan dengan insinerator. Limbah medis padat dikemas kembali dengan cara dimasukkan kedalam kantong plastik berwarna kuning. Diakui petugas tidak ada pelabelan maupun pemberian simbol/ lambang pada kemasan limbah medis yang akan dikirim. Hal ini menjadi penting dalam pelabelan agar petugas dapat mengetahui secara visual terkait pengkodean limbah medis yang berbahaya.
Tidak ada kendaraan khusus yang digunakan untuk mengangkut limbah medis dari Puskesmas Babulu ke RSUD Penajam Paser Utara. Petugas menggunakan mobil ambulance untuk mengangkut limbah medis tersebut. Jarak antara Puskesmas Babulu dengan RSUD Penajam Paser Utara sekitar $60 \mathrm{~km}$ yang ditempuh dengan perjalanan darat.

\section{Pengolahan dan pemusnahan Limbah Medis di Puskesmas Kecamatan Babulu}

Tahapan pemusnahan merupakan tahapan akhir dari pengelolaan limbah medis padat. Pemusnahan dapat dilakukan oleh pihak puskesmas sendiri maupun kerjasama dengan pihak ketiga. Hasil penelitian di tiga puskesmas, terdapat dua puskesmas yang melakukan pemusnahan sendiri (di dalam lingkungan puskesmas), yaitu Puskesmas Gunung Intan dan Puskesmas Sebakung Jaya. Puskesmas Babulu melakukan pemusnahan limbah medis berkerjasama dengan pihak lain. Menurut Kepmenkes No. 1204 tahun 2004 tentang Persyaratan Kesehatan Lingkungan Rumah Sakit, limbah medis padat tidak diperbolehkan membuang langsung ke tempat pembuangan akhir limbah 
domestik sebelum aman bagi kesehatan.

\section{Petugas Pengelola Limbah Medis Puskesmas di Kecamatan Babulu}

Karakteristik pengelola limbah medis padat yaitu penanggung jawab (sanitarian) dan pelaksana (petugas kebersihan) sebagai berikut.

Pengelola limbah medis padat puskesmas di Kecamatan Babulu berusia produktif sekitar 29 - 53 tahun. Penanggung jawab kesehatan lingkungan secara keseluruhan sudah berstatus Pegawai Negeri Sipil (PNS) dengan latar belakang pendidikan diploma (D3) Kesehatan Lingkungan.

Petugas pengelola limbah medis padat, dalam hal ini adalah petugas kebersihan yang melakukan pengelolaan limbah medis padat puskesmas. tidak ada pelatihan khusus yang diterima oleh petugas kebersihan baik dari pihak puskesmas, maupun dinas kesehatan setempat. Hal ini belum sesuai dengan Keputusan Kepala Bapedal No. 3 Tahun 1995 Tentang: Persyaratan Teknis Pengelolaan Limbah Bahan Berbahaya Dan Beracun, yang menyebutkan bahwa Perusahaan/ instansi wajib memberikan pelatihan secara berkala kepada petugas yang meliputi pelatihan dasar dan pelatihan khusus.

Petugas pengelola limbah medis padat di puskesmas melakukan pengumpulan limbah medis dari seluruh ruangan setiap hari, minimal satu kali sehari. Namun petugas tidak melakukan desinfeksi dan pembersihan tempat sampah setelah tempat sampah dikosongkan. Sedangkan untuk pemusnahan limbah medis, Puskesmas Babulu tidak melakukan setiap hari dikarenakan pemusnahan dilakukan diluar lingkungan puskesmas. Puskesmas Gunung Intan dan Puskesmas Sebakung Jaya melakukan pemusnahan limbah setiap hari di lingkungan puskesmas dengan cara dibakar tanpa menggunakan insinerator.

Petugas hanya menggunakan sarung tangan dan topi dalam pengelolaan limbah medis. Pihak puskesmas sendiri hanya menyiapkan APD berupa sarung tangan dan masker untuk petugas kesehatan. Diakui oleh petugas kebersihan bahwa alat pelindung diri memang perlu, namun terkadang petugas juga merasa tidak nyaman dalam menggunakannya, misalnya dalam menggunakan masker. 


\section{Standart Operating Procedure (SOP)}

Hanya terdapat 2 unit puskesmas yang memiliki SOP penanganan limbah medis, yaitu Puskesmas Babulu dan Puskesmas Gunung Intan. Beberapa hal yang ada dalam SOP tersebut tidak lagi sesuai dengan pelaksanaannya.

Instruksi kerja penanganan sampah medis di Puskesmas Gunung Intan masih belum sesuai dengan Kepmenkes No. 1204 tahun 2004 tentang Persyaratan Kesehatan Lingkungan Rumah Sakit. Beberapa langkah kerja yang belum sesuai diantaranya:

1. Petugas kebersihan mengangkut sampah medis setiap 3 hari sekali dari tiap ruangan. Hal ini belum sesuai, karena disebutkan dalam peraturan bahwa kantong plastik diangkat setiap hari atau kurang sehari apabila 2/3 bagian telah terisi limbah.

2. Petugas kesehatan lingkungan menghubungi petugas perusahaan pengelola sampah setiap 3 bulan sekali. Berarti limbah medis padat disimpan selama 3 bulan. Hal ini belum sesuai dengan peraturan yang ada, karena penyimpanan limbah medis padat harus sesuai iklim tropis yaitu pada musim hujan paling lama 48 jam dan musim kemarau paling lama 24 jam.

\section{Status Kesehatan Petugas Pengelola Limbah}

Dari hasil wawancara diketahui bahwa petugas kebersihan yang menangani langsung limbah medis padat tidak mengalami keluhan kesehatan yaitu gangguan pada saluran pernafasan. Untuk kejadian tertusuk limbah medis benda tajam, petugas kebersihan mengakui belum pernah mengalaminya, karena selama ini limbah medis benda tajam dikumpulkan dalam safety box.

\section{SIMPULAN}

Berdasarkan hasil penelitian dan pembahasan, diperoleh simpulan sebagai berikut.

1. Karakteristik limbah medis puskesmas di Kecamatan Babulu Kabupaten Penajam Paser Utara yaitu limbah berbahaya infeksius dan limbah berbahaya noninfeksius yang bersumber dari kegiatan pelayanan kesehatan dan tindakan medis.

2. Tahapan dalam pengelolaan limbah medis puskesmas di Kecamatan Babulu Kabupaten Penajam Paser Utara belum sesuai dengan ketentuan yang ada terutama pada tahap pewadahan, pengangkutan, penyimpanan dan pemusnahan, tetapi dari pihak 
Puskesmas telah melakukan upaya dalam pengelolaan limbah medis tersebut.

3. Petugas pengelola limbah medis puskesmas di Kecamatan Babulu Kabupaten Penajam Paser Utara berusia produktif namun tidak memiliki pendidikan dan pelatihan khusus mengenai pengelolaan limbah medis puskesmas. Penggunaan APD masih belum sesuai dengan ketentuan yang berlaku.

4. Sarana pengelolaan limbah medis puskesmas di Kecamatan Babulu Kabupaten Penajam Paser Utara yang ada yaitu wadah pemisahan limbah namun masih belum sesuai ketentuan, sedangkan alat pengangkut dan insinerator belum ada di setiap puskesmas, namun dari pihak puskesmas telah mengupayakan proses tersebut dengan cara yang aman.

5. SOP yang digunakan dalam pengelolaan limbah medis puskesmas di Kecamatan Babulu Kabupaten Penajam Paser Utara belum sesuai, namun telah berupaya menyesuaikan kondisi yang ada di puskesmas.

6. Dampak kesehatan yang dikeluhkan petugas pengelola limbah medis padat dalam pengelolaan limbah medis puskesmas di Kecamatan
Babulu Kabupaten Penajam Paser Utara sementara ini tidak ada gangguan.

\section{DAFTAR PUSTAKA}

Arikunto. 2006. Prosedur Penelitian Suatu Pendekatan Praktis. Jakarta: PT. Rineka Cipta.

Anies, 2006. Manajemen Berbasis Lingkungan Solusi mencegah dan Menanggulangi Penyakit Menular, Elex Media Komputendo, Jakarta

Departemen Kesehatan RI. 2008. Pedoman Pencegahan dan Pengendalian Infeksi di Rumah Sakit dan Fasilitas Pelayanan Kesehatan Lainnya. Jakarta

Departemen Kesehatan RI 2004, Kepmenkes $\mathrm{RI}$ No.1204/Menkes/SK/X/200 4 Tentang Persyaratan Kesehatan Lingkungan Rumah Sakit, Jakarta: Depkes RI.

Dirjen PP \& PL Kemenkes RI. 2013. Informasi Pengendalian Penyakit dan Penyehatan Lingkungan. Jakarta

Dirjen PP \& PL Kemenkes RI. 2014. Profil Pengendalian Penyakit dan Penyehatan Lingkungan.

Kementerian Kesehatan RI. 2004. Keputusan Menteri 


\begin{tabular}{|c|c|}
\hline Kesehatan No. & $\begin{array}{l}\text { Hidup. Sekretariat Negara. } \\
\text { Jakarta }\end{array}$ \\
\hline 1204/MENKES/SK/X/2004 & Jakarta \\
\hline Persyaratan & Subairi. 2015. Lokasi Limbah \\
\hline Lingkungan & Medis B3 Disegel. Koran \\
\hline Rumah Sakit. Jakarta & Sindo 27 Februari 2015 \\
\hline Kesehatan & http://www.koran- \\
\hline 2006. Keputusan Menteri & sindo.com/read/969851/15 \\
\hline $\begin{array}{l}\text { Kesehatan No. } \\
\text { 1428/MENKES/SK/XII/200 }\end{array}$ & $\begin{array}{l}\text { 1/lokasi-limbah-medis-b3- } \\
\text { disegel-1425020531 }\end{array}$ \\
\hline 6 tentang Pedoman & Sugiyono, 2014. Memahami \\
\hline Penyelenggaraan & Penelitian \\
\hline Lingkungan & Bandung : CV. Alfabeta \\
\hline Puskesmas. Jakarta & Manajemen \\
\hline Kesehatan & Puskesmas \\
\hline 2014. Peraturan Menteri & Paradigma Sehat. Jakarta \\
\hline Kesehatan No. 75 tahun & CV. Sagung Seto. \\
\hline tentang & WHO. 2011. Health-care waste \\
\hline $\begin{array}{l}\text { Kesehatan } \\
\text { Jakarta }\end{array}$ & $\begin{array}{l}\text { management. } \\
\text { http://www.who.int/mediac }\end{array}$ \\
\hline Moleong, Lexy & entre/factsheets/fs281/en/ \\
\hline Metodologi & WHO. 2011. Waste from health \\
\hline Kualitatif. Bandung : PT. & activities \\
\hline Rosdakarya & http://www.who.int/mediac \\
\hline Offset. & /factsheets/fs2 \\
\hline $\begin{array}{c}\text { Notoatmodjo. 2005. Metodologi } \\
\text { Penelitian } \\
\text { Kesehatan. }\end{array}$ & $\begin{array}{l}\text { WHO. 2014. Safe managemen } \\
\text { of wastes from health-care }\end{array}$ \\
\hline $\begin{array}{c}\text { Republik Indonesia. } 2009 . \\
\text { Peraturan Pemerintah No. }\end{array}$ & $\begin{array}{l}\text { Emy Leonita, Beny Yulianto, } \\
\text { 2014, Pengelolaan Limbah }\end{array}$ \\
\hline 101 tahun 2014 tentang & Medis Padat Puskesmas \\
\hline Pengelolaan & Pekanbaru \\
\hline Bahan Berbahaya dan & (online) \\
\hline Beracun. Sekretariat & https://www.researchgate. \\
\hline Negara. & net/publica \\
\hline Indonesia. & Maulana, \\
\hline Peraturan Pemerintah No. & Pengolahan Limbah Pad \\
\hline 32 tahun 2009 tentang & Medis Dan Pengolahar \\
\hline Perlindungan & Limbah Bahan Berbahaya \\
\hline Pengelolaan & Dan Beracun $\mathrm{Di}$ Rs \\
\hline & Su \\
\hline
\end{tabular}


Dari:

http://lpp.uad.ac.id/wpcontent/uploads/2017/05/2 4.-muchsin-184-190.pdf Ahmad Yunizar, 2014 Sistem Pengelolaan Limbah Padat Pada Rs. Dr. H.Moch. Ansari Saleh Banjarmasin (online) Dari: https://ojs.uniskabjm.ac.id/index.php/ANN/a rticle/viewFile/101/96,
$\operatorname{Rr}$ Domy Line, 2013, Evaluasi Sistem Pengelolaan Sampah Di Rumah Sakit Umum Daerah Blambangan Banyuwangi (online) Dari: https://anzdoc.com/evalua si-sistem-pengelolaansampah-di-rumah-sakitumum.html. 